\title{
A Rare Comorbidity: Dermatitis Herpetiformis and Sarcoidosis - A Case Report
}

\author{
Stoyan IVANOV PAVLOV ${ }^{1}$, Irina IVANOVA IVANOVA², Hristo BOYCHEV POPOV ${ }^{3}$, \\ Maria ANGELOVA TZANEVA ${ }^{3}$, Peter IVANOV GHENEV ${ }^{3}$ \\ ${ }^{1}$ Clinic of Dermatology and Venereology, Medical University "Dr. Paraskev Stoyanov" - Varna, Bulgaria \\ ${ }^{2}$ Clinic of Gastroenterology, Medical University "Dr. Paraskev Stoyanov" - Varna, Bulgaria \\ ${ }^{3}$ Department of Pathology, Medical University "Dr. Paraskev Stoyanov" - Varna, Bulgaria \\ *Correspondence: Stoyan Ivanov Pavlov, E-mail: stoyanpavlov@abv.bg \\ DE GRUYTER \\ UDC 616.5-002:616-002.7
}

\begin{abstract}
Sarcoidosis is an enigmatic, multisystem granulomatous disease of unknown etiology and wide range of clinical presentations. Case report: A 54-year-old female presented with facial rash: polymorphic, round, infiltrated erythematous plaques, $1-3 \mathrm{~cm}$ in size, disseminated on several areas of the face. The medical history was consistent with dermatitis herpetiformis and persistent intrahepatic cholestasis. The laboratory test results suggested celiac disease (strong positivity of IgA anti-tissue transglutaminase antibodies) but upper endoscopy was not performed to confirm it. The skin biopsy revealed noncaseating epithelioid-cell granulomas, and negative direct immunofluorescence showed IgA deposits in the dermis. Sarcoidosis with cutaneous and hepatic involvement was established based on compatible clinical findings and supportive histology. The period between manifestations of Duhring disease and skin manifestations of sarcoidosis was 20 years. Conclusion: Our clinical case supports the hypothesis for common immune pathogenic factors in gluten-sensitive diseases and sarcoidosis. The simultaneous occurrence of celiac disease and sarcoidosis is rare, but should not be under recognized.
\end{abstract}

\section{Key words}

Sarcoidosis; Dermatitis Herpetiformis; Comorbidity; Wheat Hypersensitivity; Diet, Gluten-Free; Epithelioid Cells; Granuloma; Case Reports

Sarcoidosis is a systemic granulomatous disease $\checkmark$ that primarily affects the lungs and lymphoid tissues of the body, and is due to altered immune response to unidentified antigens. During the course of sarcoidosis, approximately $25 \%$ of patients develop skin involvement with diverse manifestations, thus cutaneous sarcoidosis is known as a "great imitator". The reported skin lesions, associated with specific noncaseating granulomas, are infiltrated plaques, maculopapular eruptions, subcutaneous nodules and scars, lupus pernio and rare entities like alopecia, ulcers, hypopigmented patches and ichthyosis. Hepatic involvement occurs in $5-15 \%$ of patients with sarcoidosis, including asymptomatic abnormal liver enzyme levels, hepatosplenomegaly, chronic intrahepatic cholestasis, hilar adenopathy, and BuddChiari syndrome. The diagnosis of sarcoidosis is based on compatible clinical features, accompanied by evidence of imaging studies and tissue biopsy, with all other causes of granulomas ruled out (1). Sarcoidosis has been associated with different autoimmune disorders, such as celiac disease (CD), primary biliary cirrhosis, Crohn's disease, and Sjogren's syndrome. Celiac disease is an immune-mediated enteropathy triggered by the ingestion of gluten in genetically susceptible individuals. Dermatitis herpetiformis, or Duhring disease (DD) is a rare chronic, blistering skin disorder with pathognomonic immunoglobulin A (IgA) deposits in the papillary dermis. It is considered the specific cutaneous expression of a gluten-sensitive 
enteropathy indistinguishable from $\mathrm{CD}$, that is responding to gluten withdrawal (2). More than $90 \%$ of the patients with DD exhibit characteristics of CD intestinal histology. However, the reported prevalence of classical, symptomatic CD is low, up to $12.6 \%$, based on the Mayo Clinic experience (3).

\section{Case report}

A 54-year-old woman was admitted to the Dermatology Clinic for evaluation of facial rash presenting with polymorphic, disseminated, round, infiltrated erythematous plaques,_1 $-3 \mathrm{~cm}$ in size, bilaterally affecting the zygomatic and suborbital

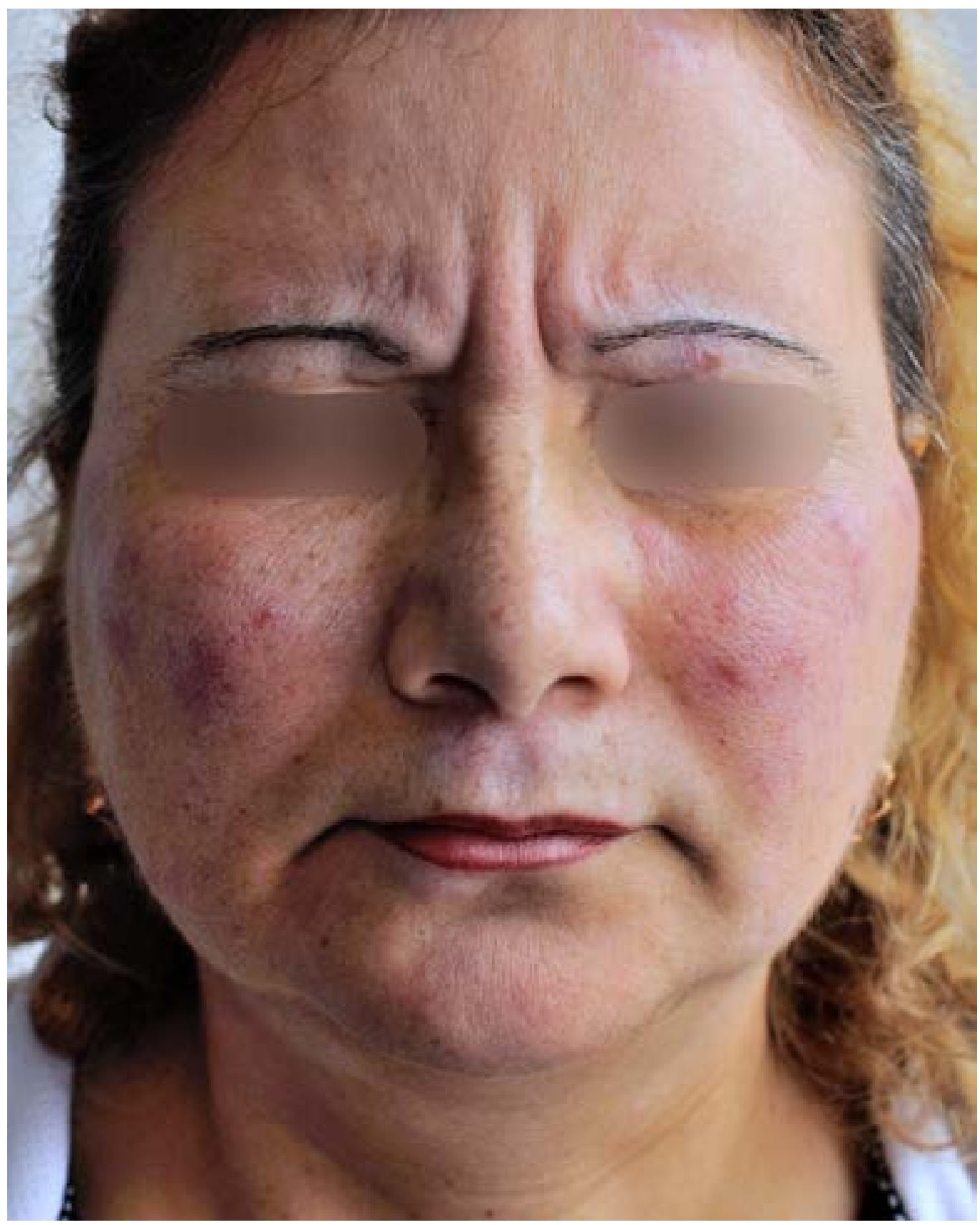

Figures 1a. The appearance of the affected skin 


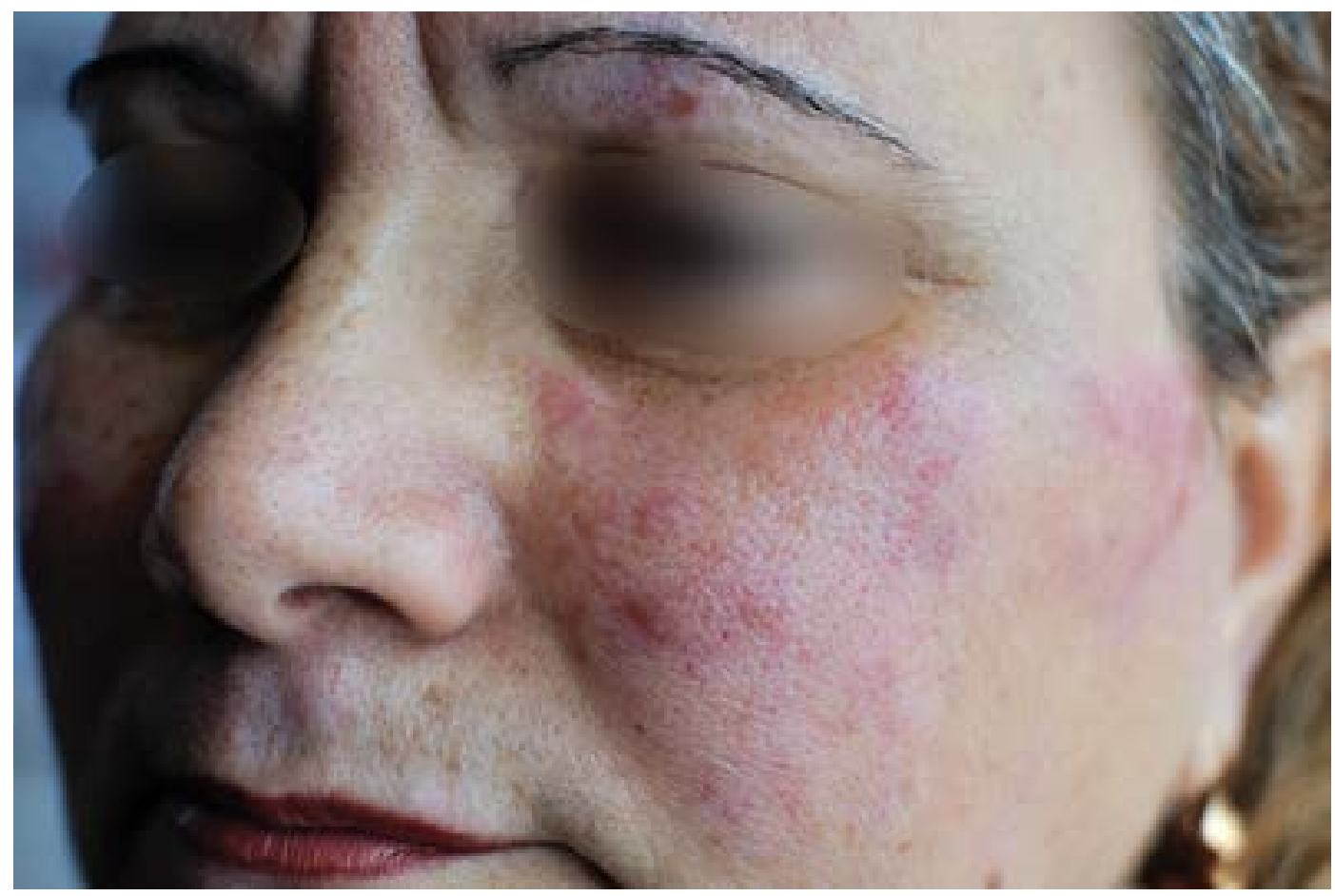

Figures $\mathbf{1 b}$. The appearance of the affected skin

areas, the left pre-auricular area, and the forehead. Several telangiectasia were also found on affected regions (Figure 1). No systemic signs and symptoms of chronic inflammation or gastrointestinal complaints were observed.

In 1995, at the age of 34 , the patient suffered from papulovesicular eruptions, affecting the elbows, knees and the groin area, and Duhring disease was confirmed by skin biopsy and direct immunofluorescence. A gluten-free diet was prescribed, but the patient showed a poor dietary compliance. Nevertheless, resolution of the rash was achieved. In 2009, fourteen years after DD was established, she had a mild fatigue and the laboratory tests showed elevated transaminases (alanine transaminase (ALT) up to 2 times the upper limit of normal (ULN)), cholestasis (alkaline phosphatase $(A P)$ up to 3 times the ULN), normal blood count, erythrocyte sedimentation rate (ESR), C-reactive protein (CRP), serum albumin and immunoglobulin $\mathrm{G}(\mathrm{IgG})$ level, negative markers for chronic viral hepatitis, negative anti-mitochondrial autoantibodies, but positive anti-nuclear antibodies $(+++)$, antibodies to tissue transglutaminase - tTG IgA $(++)$ and antibodies to gliadin $(+)$. With a suspicion of autoimmune hepatitis, overlap syndrome with primary biliary cirrhosis, a percutaneous liver biopsy was done. Histology revealed portal fibrosis, one broad fibrotic P-P septa, scarce portal lymphoid infiltrates, balloon degeneration of hepatocytes, numerous granulomas in the lobules containing lymphoid, epithelioid and fibroblast cells, few giant multinuclear cells and eosinophils (Figure 2).

The past medical history of our patient showed dermatitis herpetiformis (Duhring disease) and chronic granulomatous hepatitis; celiac disease is a presumptive diagnosis, but the patient refused upper endoscopy and endoscopic and histological proof of celiakia was not obtained. Treatment with low-dose oral methylprednisolone ( $4 \mathrm{mg}$ per day), azathioprine (50 $\mathrm{mg}$ per day) and ursodeoxycholic acid (750 $-1000 \mathrm{mg}$ per day) was introduced in 2009 , but with frequent interruptions, and the patient again failed to follow a strict gluten-free diet. Remission of_DD was achieved, however cholestatic liver enzymes remained slightly elevated.

In 2015, on current admission, a biopsy of the affected facial skin was done and the histology report supported skin involvement of sarcoidosis (epithelioid 
granulomas without caseous necrosis, few giant/ Langerhans cells, surrounding tissue with lymphoid infiltrates and very mild perivascular mononuclear infiltrations and negative immunofluorescence findings for $\operatorname{IgG}$, IgA, IgM and C3) (Figures 3a and $3 b)$.

Retrospectively, sarcoidosis can be established to correlate with chronic, relatively benign course of disease with a period of 6 years between diagnosis of hepatic and cutaneous involvement.

The patient provided a written informed consent for planned examinations and use of the results for scientific purposes.

\section{Discussion}

Sarcoidosis is a chronic idiopathic granulomatous disease. Extra-thoracic involvement is not rare, and it can initiate the course of sarcoidosis. Systemic workup is necessary in patients with histological findings of sarcoid-like granulomas to rule out tuberculosis and other (fungal, parasitic) infections, as well as a first signs of lymphoma or a systemic autoimmune disease. The association of sarcoidosis, as a chronic idiopathic granulomatous disease, and $\mathrm{CD}$ has previously been described $(4-10)$. Reports linking sarcoidosis and DD are less numerous. Large cohort studies of patients with DD found occurrence of concomitant sarcoidosis in $1.3 \%$ to $1.5 \%$ of patients, and the mean interval between diagnoses was 1 year $(3,11)$. Strong association with class II haplotype HLA-DR3, DQ2

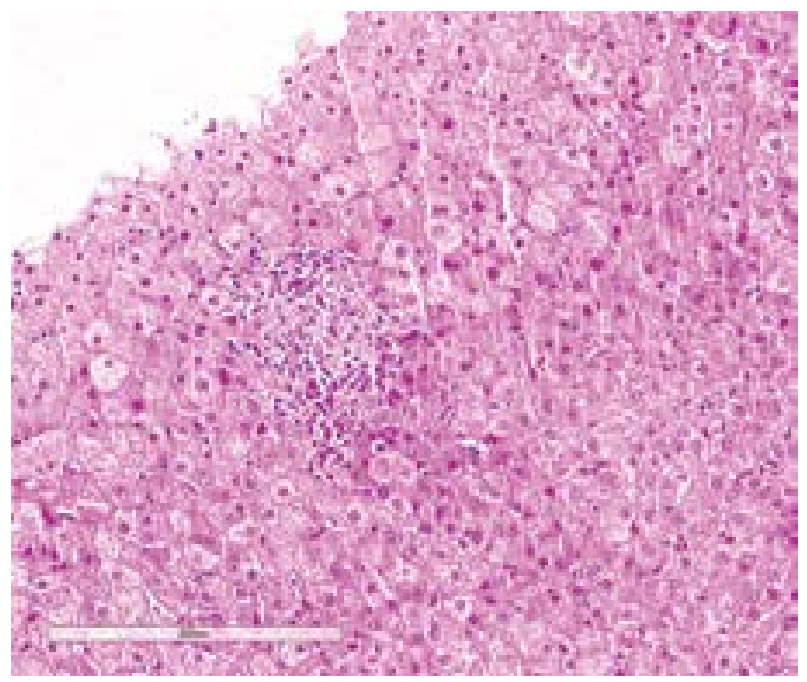

Figure 2. Histology of a blind liver biopsy suggesting chronic granulomatous hepatitis

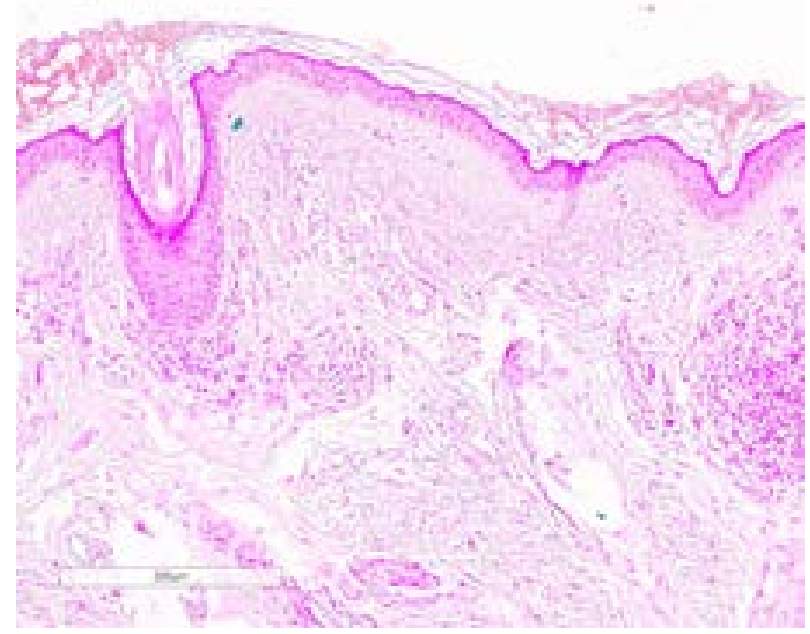

Figure 3a. Histology of skin biopsy, consistent with cutaneous sarcoidosis (hematoxylin and eosin staining)

and HLA-B8 have been demonstrated in sarcoidosis, $\mathrm{CD}$ and DD, and these disorders probably share immunological disturbances $(2,4)$. Enhancing the expression of class II HLA molecules, diseases may predispose to each other (9). The manifestations of sarcoidosis seem to improve during a gluten free diet and relapse after reintroduction of gluten into the diet (10). Because sarcoidosis and CD have variable, atypical presentations, the physicians should be aware and search for their association. Also, a routine screening for CD should be considered in patients with sarcoidosis, due to a potential benefit from a gluten free diet.

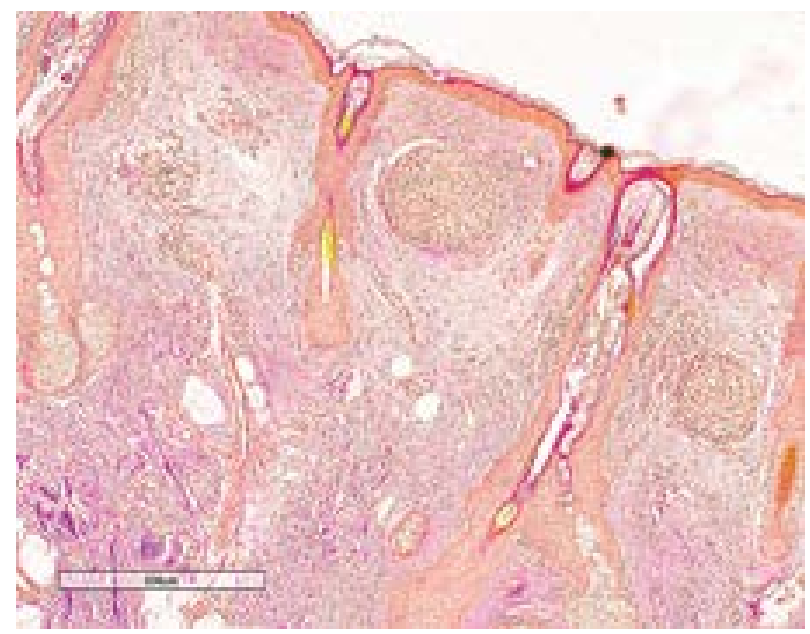

Figure 3b. Histology of skin biopsy, consistent with cutaneous sarcoidosis (Van Gieson's stain) 
On the other hand, the pathogenesis of DD is not well understood (2). In our case we observed a clinical remission of $\mathrm{DD}$ at the time when manifestations of hepatic granulomatosis appeared, and negative direct immunofluorescence test for DD during investigations of skin sarcoidosis. Interestingly, DD patients show high rate of positivity (16 of 17 of cases) of in vitro Kmif test for cellular immunity, characteristic for disorders with epithelioid granulomas (12). Another study suggests the common role of human macrophage metalloelastase (MMP-12) for elastin degradation occurring in granulomatous skin diseases and for macrophage migration through the epidermal and vascular basement membranes in skin inflammatory disorders, such as DD (13). Therefore, our case report may be a small contribution to the concept of a common genetic predisposition and pathogenesis of DD and sarcoidosis.

\section{Abbreviations}

CD - celiac disease
DD - Duhring disease
IgA - immunoglobulin A
ALT - alanine transaminase
ULN - upper limit of normal
AP - alkaline phosphatase
IgG - immunoglobulin G
tTG - tissue transglutaminase
MME-12 - macrophage metalloelastase-12

\section{References}

1. Iannuzzi MC, Rybicki BA, Teirstein AS. Sarcoidosis. N Engl J Med. 2007;357(21):2153-65.

2. Caproni M, Antiga E, Melani L, Fabbri P, Italian Group for Cutaneous Immunopathology. Guidelines for the diagnosis and treatment of dermatitis herpetiformis. J Eur Acad Dermatol Venereol. 2009;23(6):633-8.

3. Alonso-Llamazares J, Gibson LE, Rogers RS. Clinical, pathologic, and immunopathologic features of dermatitis herpetiformis: review of the Mayo Clinic experience. Int J Dermatol. 2007;46(9):910-9.

4. Rutherford RM, Brutsche MH, Kearns M, Bourke M, Stevens F, Gilmartin JJ. Prevalence of coeliac disease in patients with sarcoidosis. Eur J Gastroenterol Hepatol. 2004;16(9):911-5.

5. D'Ercole C, Zullo A, Bragazzi MC, Campo SM. Sarcoidosis and coeliac disease: do not forget the association! Intern Emerg Med. 2012;7 Suppl 1:S25.

6. Douglas JG, Gillon J, Logan RF, Grant IW, Crompton GK. Sarcoidosis and coeliac disease: an association? Lancet. 1984;2(8393):13-5.

7. Reunala T. Dermatitis herpetiformis: coeliac disease of the skin. Ann Med. 1998;30(5):416-8.

8. Hwang E, McBride R, Neugut AI, Green PH. Sarcoidosis in patients with celiac disease. Dig Dis Sci. 2008;53(4):977-81.

9. Ludvigsson JF, Wahlstrom J, Grunewald J, Ekbom A, Montgomery SM. Coeliac disease and risk of sarcoidosis. Sarcoidosis Vasc Diffuse Lung Dis. 2007;24(2):121-6.

10. Loche F, Bazex J. Celiac disease associated with cutaneous sarcoidosic granuloma. Rev Med Interne. 1997;18(12):975-8.

11. Reunala T, Collin P. Diseases associated with dermatitis herpetiformis. Br J Dermatol. 1997;136(3):315-8.

12. Pagaltsos AS, Kumar PJ, Willoughby JM, Dawson AM. In-vitro inhibition of leucocyte migration by sarcoid spleen suspension in coeliac disease and dermatitis herpetiformis. Lancet. 1971;298(7735):117981.

13. Vaalamo M, Kariniemi AL, Shapiro SD, Saarialho-Kere U. Enhanced expression of human metalloelastase (MMP-12) in cutaneous granulomas and macrophage migration. J Invest Dermatol. 1999;112(4):499-505.

\section{Dermatitis herpetiformis i sarkoidoza - redak komorbiditet - prikaz slučaja}

\section{Sažetak}

Uvod. Sarkoidoza je zagonetna, multisistemska granulomatozna bolest nepoznate etiologije sa širokim spektrom kliničkih simptoma. Prikaz slučaja. Pacijentkinja stara 54 godine primljena je na Kliniku za dermatologiju sa osipom na licu: polimorfni, okrugli, infiltrirani eritematozni plakovi, veličine $1-3 \mathrm{~cm}$, bili su rasuti po delovima lica. Istorija bolesti je ukazivala na dermatitis herpetiformis i perzistentnu intrahepatičku holestazu. Rezultati laboratorijskih testova ukazivali su na celijakiju (visoka pozitivnost $\operatorname{Ig} A$ anti-transglutaminska antitela), ali gornja endoskopija nije urađena da to potvrdi. Biopsija kože otkrila je nenekrotizirajuće epitelioidne ćelije granuloma, a negativna direktna imunofluorescencija pokazala je IgA depozite u dermisu. Sarkoidoza kože i jetre ustanovljena je na osnovu kompatibilnosti kliničkog i histopatoloških nalaza. Između manifestacija Duringove bolesti i kožnih manifestacija sarkoidoze prošlo je 20 godina. Zaključak. Naš klinički slučaj podržava hipotezu 
da su patogeni imunofaktori zajednički kod bolesti osetljivih na gluten i sarkoidozu. Istovremena pojava celijakije i sarkoidoze je retka, ali ne bi trebalo da bude neprepoznata.

\section{Ključne reči}

Sarkoidoza; Dermatitis herpetiformis; Komorbiditet; Hipersenzitivnost na pšenicu; Bezglutenska ishrana; Epiteloidne ćelije; Granulom; Prikazi slučajeva 